mium could be minimized by the use of potassium persulfate fusion in the chemical pretreatment. Sensitivities (ppm/1\% absorption) were: $\mathrm{Ti} 1.4, \mathrm{~V} 1.1$,
$\mathrm{Ni} 0.3, \mathrm{Cr} 0.2, \mathrm{~Pb} 0.9$ and $\mathrm{Bi}$ 0.8. The detection limits were about one tenths of the above concentrations.

(Received Sept. 21, 1968)

\title{
差動走查熱量法，示差熱分析法および熱重量分析法による 石こうの定量分析*
}

\author{
橋詰 源蔵， 網田 佳代子**
}

(1968 年 12 月 2 日受理)

\begin{abstract}
差動走查熱量計 (DSC) による $\mathrm{CaSO}_{4} \cdot 2 \mathrm{H}_{2} \mathrm{O}-\mathrm{CaSO}_{4} \cdot 1 / 2 \mathrm{H}_{2} \mathrm{O}, \mathrm{CaSO}_{4} \cdot 1 / 2 \mathrm{H}_{2} \mathrm{O}-\mathrm{CaSO}_{4}$ 各混合 系の定量分析方法について検討した。

$\mathrm{CaSO}_{4} \cdot 2 \mathrm{H}_{2} \mathrm{O}-\mathrm{CaSO}_{4} \cdot 1 / 2 \mathrm{H}_{2} \mathrm{O}$ 混合系の分析において, $\mathrm{CaSO}_{4} \cdot 2 \mathrm{H}_{2} \mathrm{O}$ の 2 段階の加熱脱水に相当 する二つの吸熱ピークを明りょうに分離させるための測定条件について検討した。 その結果, 試料容器 としてふたに小さなピンホールをあけたアルミ製の密封型の容器を用い，昇温速度を大きくして測定し た場合にピークの分離は良好であった。またこの測定条件では, 測定誤差の一つの原因になると考光ら 机る $\mathrm{CaSO}_{4} \cdot 1 / 2 \mathrm{H}_{2} \mathrm{O}$ の脱水ピークのあとに現わ机る $\mathrm{CaSO}_{4}$ の結晶化による発熱ピークが小さくな った.

DSC による方法と従来より行な秃ている示差熱分析法および熱重量分析法と比較した結果，DSC による方法注迅速でしかも精度のよい方法であることがわかった。
\end{abstract}

\section{1 緒言}

焼き石こうとして一般に用いられている硫酸カルシウ 么の半水和物（以下半水石こうという）中には，乙ばし ば硫酸カルシウムの 2 水和物（以下 2 水石こうという） が混在し，また最近では，水に可溶性である(III) 型の 結晶形を有する無水の硫酸カルシウム（以下無水石こう という）を含导焼き石こうが製造されている.

焼き石こうの品質は，その中に混在する 2 水不こう亦 るい流無水石こうの量によって著しく左右される。した がってその組成を知ること注重要なことである.

分析方法について洼従来より種々検討さ机ている・た 上え壮 2 水，半水および無水石こうの結晶形の差を利用 したX線回折による分析法122)，2水および半水石こうの 加熱による脱水を利用した示差熱分析法（以下 DTA 法 上略記) ${ }^{3)}$ および熱重量分析法 (以下 TGA 法之略記) ${ }^{4)}$

* 差動走査熱量法，示差熱分析法および熱重量分析法 による工業分析法の研究 (第 1 報)

**兵庫県立工業試験場 : 神戸市須磨区行平町 3 丁目
などがある・こ秃らの諸方法のうちの DTA 法に対応し て，最近になって開発され，その利用が急速に広めら机 つつある差動走查熱量計を用いる方法（以下 DSG 法と 略記）がある.

ここで DTA 装置々DSC を簡単に比較するＤＤTA 注試料と不活性標準試料々の間の温度差を測定するのに 対し，DSC 注試料と標準試料の各ホルダーを同一温度 に保つために補償回路から供給される電力を記録する。 しかもチャート紙上に記録されたピークの面積はかなり 正確に熱量に比例する。また小さな試料ホルダー法加熱 炉を兼权ており，その熱容量が小さいので加熱速度は最 大で 1 分間 $80^{\circ} \mathrm{C}$ 上非常に大きく, 乙かも装置に試料を 入れて所定の温度にセットして測定を開始するまでに要 する時間は数分以内である.

著者らはこの上うな特徴をもつDSCを中心にして熱 分析法による工業分析法を検討していく予定であるが， 本報では DSC 法による石こうの分析法について検討し た結果およびそれと従来の方法すなわちDTA 法，TGA 法との比較について報告する。 


\section{2 実験}

\section{1 試 料}

2 水石こう：塩化カルシウム水溶液と硫酸ナトリウム 水溶液を反応させ, 得られた 2 水石こうの沈殿をろ過し 蒸留水で洗浄したのち, 乾燥を速くするためにメチルア ルコールとエチルエーテルを流しょく吸引したのち 80 “而で乾燥した。

半水石こう：上記の 2 水石こうを硝酸中で加熱脱水す ることにより調製したゔ。. ろ過乾燥の手順は 2 水石こう の場合と同様である.

無水石こう：さきの 2 水石こうを $250^{\circ} \mathrm{C}$ で 8 時間加 熱脱水して調製した.

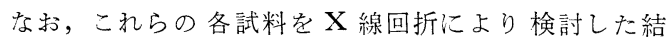
果, 各試料とも他の石こうの存在は認められなかった。

\section{$2 \cdot 2$ 装置および測定条件}

\subsubsection{DTA 法および TGA 法装置は理学電機}

（株）製の複数炉型の 自動記録式示差熱天びえ 装置で， DTA およで TGA の同時測定が行なえるものを使用し た、試料容器は白金製で, 直径 $7 \mathrm{~mm}$, 深さ $19 \mathrm{~mm}$ の ものを用い,これに $300 \mathrm{mg}$ の試料を詰めて測定に供し た。装置の操作条件は示差感度 $\pm 500, \pm 250 \mu \mathrm{V}$, 重 量感度 $\pm 50, \pm 25 \mathrm{mg}$, 昇温速度 $5^{\circ} \mathrm{C} / \mathrm{min}$, 記録紙速 度 $180 \mathrm{~mm} / \mathrm{hr}$ であった。なお，不活性標準試料として は $\alpha$ ーアルミナを使用した。

参考のために 2 水石こうと半水石こうを $5: 5$ の割合 で混合した試料の DTA 曲線と TGA 曲線を Fig. 1 亿 示した。またDTA ピークの大きさの測定法および重量 変化の測定法もあわせて示した。なお簡単にするために 2 水石こうが脱水して半水石こうに変化する反応に相当

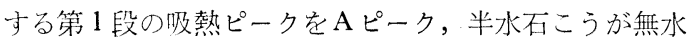
石こうに変化する脱水反応に対応する第 2 段の吸熱ピー クをBピークと呼ぶこと沈する。

2.2.2 DSC 法装置はパーキンエルマー社製の DSC-1B 型を用いた。試料ざらはアルミ製のものを用い た. 測定の条件については次に述べる.

2.2•3 DSG 法による測定条件の検討 開放型の試 料ざらを用い，2水石こうと半水石こうを $5: 5$ の割合 で混合した試料を乾燥窒素気流中で DSC で測定したサ ーモグラムをFig. 2の (I)に示した.この測定条件では ピークの立ち上がり注明確でなく, 二つのピークの分離 も良好でない。したがってピークの高さまたは面積を測 定するためのベースラインの取り方が困難であることが わかる・このことより面積測定の方法を簡便にし，誤差 虑少なくするためには，ピークの分離をよくする測定条 件が必要であると考えられる。なお，DTA 法に打ける

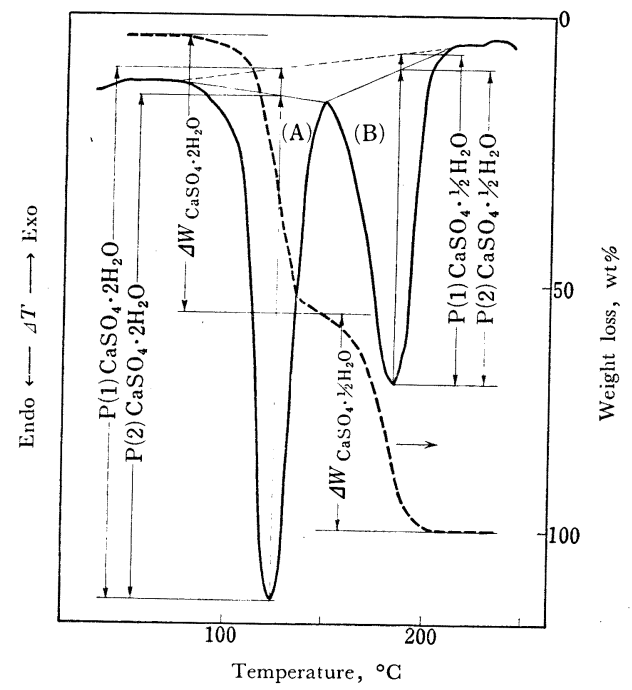

Fig. 1 DTA and TGA curves of the mixture of dihydrate and hemihydrate (5:5), and measuring methods of DTA peak intensity Range : $\pm 250 \mu \mathrm{V} ; \quad$ Heating rate $: 5^{\circ} \mathrm{C} / \mathrm{min} ; \quad$ Sample weight : $300 \mathrm{mg} ;$ Atmosphere : Air

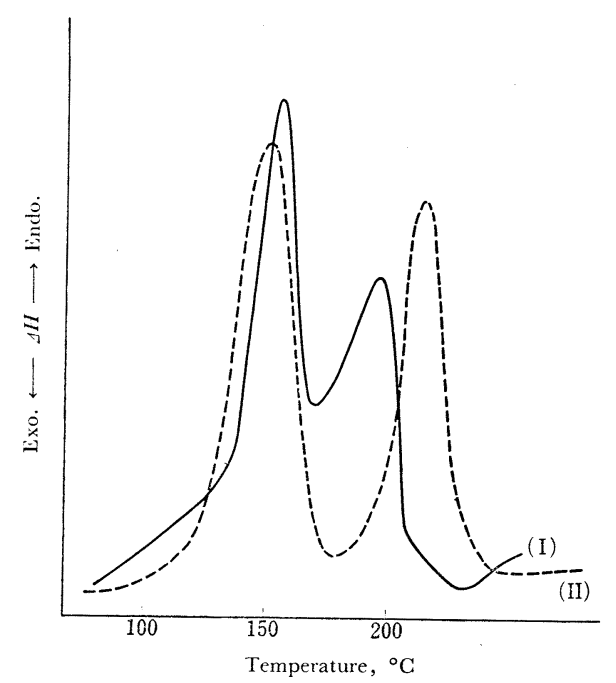

Fig. 2 DSC curves of the mixture of dihydrate and hemihydrate $(5: 5)$, at heating rate $40^{\circ} \mathrm{C} / \mathrm{min}$

(I) Sample pan : Open, Atmosphere $: \mathrm{N}_{2}$; (II) Sample pan : Pin hole pan; Atmosphere : Self-atmosphere

これらのピークの分離注, 試料容器に試料詰める方法 を考慮するここにより，かなり良好になるが完全ではな (3).

宮崎(は6)， 2 水石こうの 2 段の加熱脱水反応が水蒸気 
分压の大きな影響を受けること，すなわち減圧あるいは 乾燥気流中での DTA 曲線は 2 本の吸熱ピークを示さ ず， 2 水石こうから無水石こうまでの変化に相当する 1 本の吸熱ピークのみを示すのに対し, 分解時における水 蒸気分圧が高いほど 2 本の吸熱ピークの温度差は大きく なり，また分離もよくなることを示した：これらのこと を考慮して, 試料の詰め方, 測定のふんい気の影響につ いて検討した．普通の方法すなわち開放型の試料容器を 用い, 窒素気流中（I）で昇温速度を变えた場合のピー ク温度変化と, 試料容器としてふたに小さなピンホール をあけた密封型の容器を用い, 乾燥窒素を流さずに (II), 昇温速度を変化させた場合のピーク温度変化とを Fig. 3 に示した. Fig. 3 より明らかなように，(I) の測定法よ りも，(II）の測定法のほうが二つのピークの温度差は 大きくなり, 昇温速度 $20^{\circ} \mathrm{C} / \mathrm{min}$ のときに温度差は最 高になるが，第 1 段の脱水ピークのティリングは昇温速 度 $40^{\circ} \mathrm{C} / \mathrm{min}$ のほうがより少なくなり，ピークの分離 はよくなる. 2 水石こうと半水石こう崖 $5: 5$ の割合で 混合した場合にも同じ傾向を示寸（II）の方法でふた をはずし，窒素気流中で測定すれば，二つのピークの温 度差はますます小さくなり，分離がわるくなる。これら

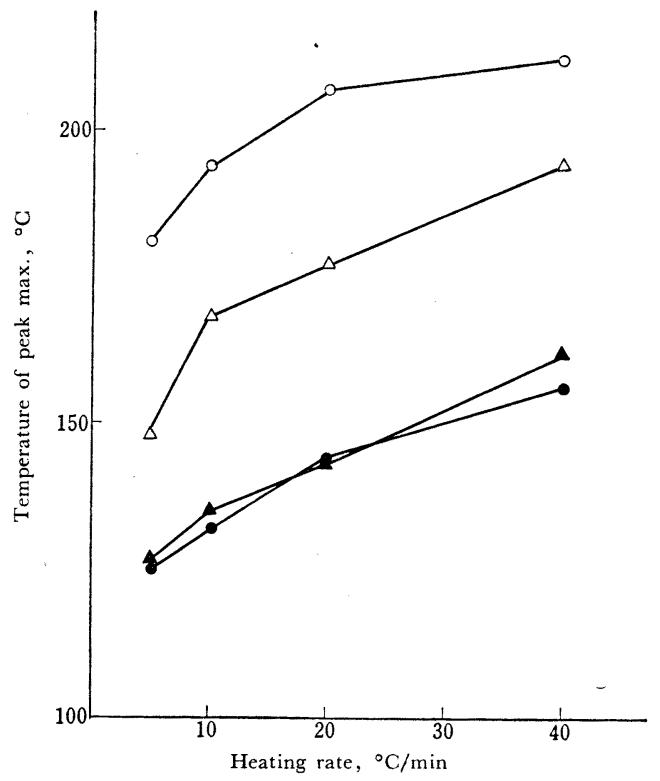

Fig. 3 Effect of heating rate and sample pan on the temperature of the peak max. of $\mathrm{CaSO}_{4} \cdot 2 \mathrm{H}_{2} \mathrm{O}$

-O- Peak A : Pin hole sample pan, self-atmosphere; $-\triangle-$ Peak A : Open sample pan, $\mathrm{N}_{2} ;---$ Peak B : Pin hole sample pan, self-atmosphere; $-\boldsymbol{\Lambda}-$ Peak B : Open sample pan, $\mathrm{N}_{2}$
のことから，(II)の方法で昇温速度 $40^{\circ} \mathrm{C} / \mathrm{min}$ で測定し た場合に，ピークの立ち上がりおよび分離が他の昇温速 度で測定した場合に比べていっそう良好になることは， 昇温速度 $40^{\circ} \mathrm{C} / \mathrm{min}$ の測定条件のほうが 水蒸気分圧の 高いふえい気にあるためと考えら机る。なお，2水石こ うと半水石こうを $5: 5$ で混合した試料のサーモグラム を Fig.2の(II) に示した.

また Fig. 2 の（I）と（II）を比較すると，(I) は二 つの吸熱ピークの現われたのちに発熱ピークが認められ る.この発熱ピークは半水石こう単独を, 開放型の試料 容器を用い，窒素気流中で測定した場合に，2 水石こう よりも顕著に現われるが，双方とも(II) の測定方法它 用いることにより発熱ピークはほぼ消える. この原因と して, 水蒸気の存在により, 脱水後の無水石こうの結晶 化が促進されるためと推察される。

なお, 半水石こうでは, 開放型の試料容器を使用し, 窒素気流中で測定を行ない，面積測定は低温側バックグ ラウンドを延長して行なった。

次に試料量とピークの大きさとの関係を検討した結 果, 試料量とピーク面積の間にはよい直線関係があるこ とがわかった。このこととひょう量誤差および試料容器 への試料封入の難易性を考慮して，1 回の測定試料量は 約 $10 \mathrm{mg}$ とした.

\section{3 結果と考察}

検量線は 2 水石こう一半水石こう混合系および半水石 こう一無水石こう混合系についてそれぞれ $1: 9,3: 7$, $5: 5,7: 3,9: 1$ の割合の混合物から作製した。 また その再現性は 1:9，5:5 の混合試料について検討し た。それらの結果を次に述べる。

\subsection{DTA 法}

3.1.1 2 水石こう-半水石こう混合系 ここには示 さなかったが，Aピークの高さ，面積およびBピークを 用いた内標準法による相対高さ，相対面積と 2 水石こう の含有量との関係は佐藤3)の結果とよく一致した.

一方，Aピーク，Bピークの高さと面積および内標準 法による相対高さ, 相対面積の標準偏差を Table I に 示した. Table I より Fig. 1 中に示した（1）の方法に よるAピークの高さの再現性が最も良好であり，標準偏 差は 5\% 以下であることがわかる。

\subsection{2 半水石こう-無水石こう混合系 B ピークの} 高さおよび面積による検量線を Fig. 4 に示した. 半水 石こうの含量とBピークの高さおよび面積との間には， いずれも良好な直線関係の成立することが認められる. 
Table I Comparison of the precision of values determined by various measuring methods of the peak intensity (DTA, $\left.\mathrm{CaSO}_{4} \cdot 2 \mathrm{H}_{2} \mathrm{O}-\mathrm{CaSO}_{4} \cdot 1 / 2 \mathrm{H}_{2} \mathrm{O}\right)$

\begin{tabular}{|c|c|c|c|c|c|c|c|}
\hline \multicolumn{2}{|c|}{$\frac{\mathrm{CaSO}_{4} \cdot 2 \mathrm{H}_{2} \mathrm{O}(\mathrm{g})}{\mathrm{CaSO}_{4} \cdot 1 / 2 \mathrm{H}_{2} \mathrm{O}(\mathrm{g})}$} & \multicolumn{3}{|c|}{$5 / 5$} & \multicolumn{3}{|c|}{$1 / 9$} \\
\hline Method & & $\begin{array}{c}\text { A } \\
\text { peak }\end{array}$ & $\begin{array}{c}\text { B } \\
\text { peak }\end{array}$ & $\begin{array}{l}\text { Ratio of } \\
\text { A/B }\end{array}$ & $\begin{array}{c}\text { A } \\
\text { peak }\end{array}$ & $\begin{array}{c}\text { B } \\
\text { peak }\end{array}$ & $\begin{array}{l}\text { Ratio of } \\
\text { A/B }\end{array}$ \\
\hline Height & (1) & 2.48 & 2.54 & 7.27 & 4.65 & 3.32 & 2.76 \\
\hline Height & (2) & 2.68 & 3.53 & 9.53 & 5.36 & 3.26 & 2.99 \\
\hline Area & (1) & 3.08 & 8.04 & 2.37 & 8.23 & 5.11 & 7.32 \\
\hline Area & (2) & 3.06 & 6.85 & 3.17 & 8.02 & 5.24 & 6.12 \\
\hline
\end{tabular}

mg ; Atmosphere : Air

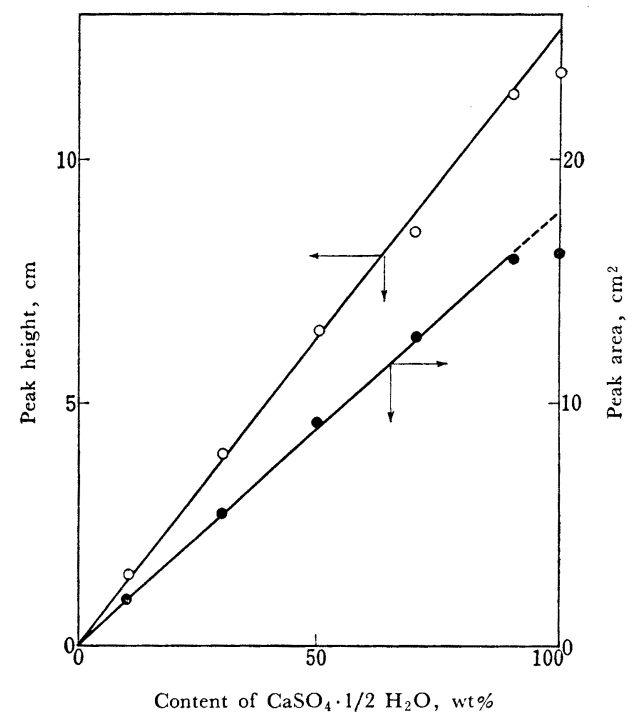

Fig. 4 Calibration curve of content of calcium sulfate hemihydrate by various determination methods (absolute) with DTA

Range: $\pm 250 \mu \mathrm{V}$; Heating rate $: 5^{\circ} \mathrm{C} / \mathrm{min}$; Sample weight : $300 \mathrm{mg}$; Atmosphere : Air; - - Peak area ; $-\mathrm{O}-$ Peak height

そしてこれらの測定值の再現性はピークの面積のほうが 良好で, Table II に示したように標準偏差は 5\% 以下 である。

\subsection{TGA 法}

この方法の再現性は Table III に示したように， 2 水石こうと半水石こうとの混合系では標準偏差 $3 \%$ 以下 であり, Table II から半水石こうと無水石こうの混合 系では $2 \%$ 以下で非常によい結果を与えることがわか 各.
Table II Precision of the determination of $\mathrm{CaSO}_{4}$. $1 / 2 \mathrm{H}_{2} \mathrm{O}$ in $\mathrm{CaSO}_{4} \cdot 1 / 2 \mathrm{H}_{2} \mathrm{O}-\mathrm{CaSO}_{4}$ by various analytical methods (\% coefficients)

\begin{tabular}{llll}
\hline $\mathrm{CaSO}_{4} \cdot 1 / 2 \mathrm{H}_{2} \mathrm{O}(\mathrm{g})$ & $5 / 5$ & $1 / 9$ \\
$\mathrm{CaSO}_{4}(\mathrm{~g})$ & & 4.87 \\
$\mathrm{DTA}$ (peak area) & 2.02 & 0.9 \\
$\mathrm{TGA}$ & 1.3 & 3.09 \\
$\mathrm{DSC}\left(40^{\circ} \mathrm{C} / \mathrm{min}\right)$ & 2.61 & 5 \\
\hline
\end{tabular}

DTA and TGA-Range : $\pm 250 \mu \mathrm{V}$, Heating rate : $5^{\circ} \mathrm{C} / \mathrm{min}$, Sample weight : $300 \mathrm{mg}$, Atmosphere : Air; DSC-Sample pan : Open, Heating rate : $40^{\circ} \mathrm{C} / \mathrm{min}$, Sample weight $: 10 \mathrm{mg}$, Atmosphere : $\mathrm{N}_{2}$

Table III Precision of values measured by TGA (coefficient \%)

\begin{tabular}{|c|c|c|c|c|}
\hline \multirow{2}{*}{$\frac{\mathrm{CaSO}_{4} \cdot 2 \mathrm{H}_{2} \mathrm{O}(\mathrm{g})}{\mathrm{CaSO}_{4} \cdot 1 / 2 \mathrm{H}_{2} \mathrm{O}(\mathrm{g})}$} & \multicolumn{2}{|c|}{$5 / 5$} & \multicolumn{2}{|c|}{$1 / 9$} \\
\hline & $\underset{2 \mathrm{HaSO}_{2} \mathrm{O}}{\mathrm{C}_{4}}$ & $\begin{array}{l}\mathrm{CaSO}_{4} \cdot \\
1 / 2 \mathrm{H}_{2} \mathrm{O}\end{array}$ & $\begin{array}{c}\mathrm{CaSO}_{4} \\
2 \mathrm{H}_{2} \mathrm{O}\end{array}$ & $\begin{array}{l}\mathrm{CaSO}_{4} \cdot \\
1 / 2 \mathrm{H}_{2} \mathrm{O}\end{array}$ \\
\hline Relative std. dev. (\%) & 2.0 & 3.0 & 2.8 & 1.3 \\
\hline
\end{tabular}

Range : $\pm 250{ }_{\mu} \mathrm{V} ;$ Heating rate $: 5^{\circ} \mathrm{C} / \mathrm{min}$; Sample weight : 300 mg; Atmosphere : Air

\subsection{DSC 法}

3.3.1 2 水石こう-半水石こう混合系 Fig. 5 に昇 温速度 $40^{\circ} \mathrm{C} / \mathrm{min}$ における ピーク面積と 2 水石こうの 含量との関係を示し，Table IV に昇温速度の異なる場

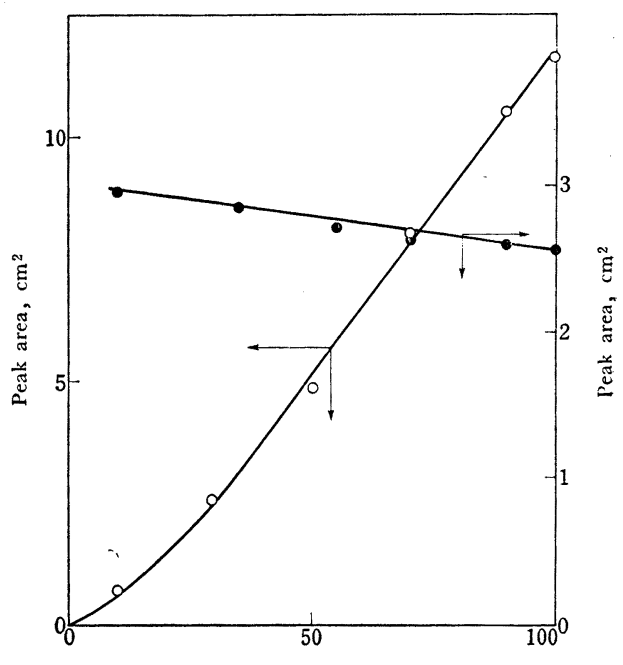

Content of calcium sulfate hydrate, wi \%

Fig. 5 Calibration curve of A and B peak area vs. content of calcium sulfate dihydrate by absolute method with DSC

Heating rate : $40^{\circ} \mathrm{C} / \mathrm{min}$; Sample pan : Pin hole sample pan ; Atmosphere : Self-atmosphere; Sample weight : $10 \mathrm{mg}$; - $\mathrm{O}-\mathrm{A}$ peak ; - $-\mathrm{B}$ peak 
Table IV Relative standard deviation (\%) of values measured by DSC at various) heating rate

\begin{tabular}{|c|c|c|c|c|c|c|c|}
\hline \multicolumn{2}{|c|}{$\frac{\mathrm{CaSO}_{4}}{\mathrm{CaSO}_{4}} \cdot \frac{2 \mathrm{H}_{2} \mathrm{O}}{1 / 2 \mathrm{H}_{2} \mathrm{O}(\mathrm{g})}$} & \multicolumn{3}{|c|}{$5 / 5$} & \multicolumn{3}{|c|}{$1 / 9$} \\
\hline & & \multicolumn{2}{|c|}{ Peak area } & \multirow{2}{*}{$\begin{array}{c}\text { Ratio of } \\
\text { peak } \\
\text { area } \\
\text { A/B }\end{array}$} & \multicolumn{2}{|c|}{ Peak area } & \multirow{2}{*}{$\begin{array}{l}\text { Ratio of } \\
\text { peak } \\
\text { area } \\
\mathrm{A} / \mathrm{B}\end{array}$} \\
\hline & & $\begin{array}{c}\mathrm{A} \\
\text { peak }\end{array}$ & $\overbrace{\text { peak }}^{\mathrm{B}}$ & & $\begin{array}{c}\mathrm{A} \\
\text { peak }\end{array}$ & $\underset{\text { peak }}{\text { B }}$ & \\
\hline \multirow{4}{*}{$\begin{array}{l}\text { Heating rate } \\
\left({ }^{\circ} \mathrm{C} / \mathrm{min}\right)\end{array}$} & 5 & 2.21 & 5.16 & 14.13 & 16.35 & 14.47 & 22.54 \\
\hline & 10 & 2.65 & 7.75 & 6.70 & 4.18 & 5.00 & 6.07 \\
\hline & 20 & 2.23 & 3.51 & 3.98 & 3.43 & 3.42 & 4.39 \\
\hline & 40 & 2.28 & 2.83 & 1.86 & 2.68 & 2.63 & 2.28 \\
\hline
\end{tabular}

Sample pan : Pin hole pan; Atmosphere : Self-atmosphere;

Sample weight $: 10 \mathrm{mg}$

合における測定值の再現性を示した。測定値の再現性法 昇温速度 $40^{\circ} \mathrm{C} / \mathrm{min}$ の場合が最も良好である。

$40^{\circ} \mathrm{C} / \mathrm{min}$ 以外の昇温速度で測定した場合, 測定值の 流らつき法やや大きいが， $40^{\circ} \mathrm{C} / \mathrm{min}$ 之同じ傾向を示し た。また Bピークの再現性はAピーク上りもわるく, し ふも昇温速度が小さくなるほど偏差注大きくなっている ことがわかる。このことより熱分解に及洁すふれい気の 影響は 2 段目の脱水反応ピークに，上りいっそう大きな 影響を及ぼすもの之考元られる。

Fig. 5 に示した 2 水石こうの検量線法 DTA の場合上 同椂に湾曲している。この原因としては, 試料の熱容量 の変化, 熱伝尊度の差などが考えられる.Fig. 6 法熱容 量, 熱伝導の異なるグラファイト上 $\alpha$-アルミナをそれ

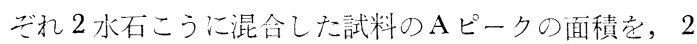
水石こうの単位重量あたりに換算した檤之混合割合との 関係を示したものだある. Fig. 7 注同様のことを半水石 こうについて求めた結果である. Fig. 6 より，グラフ イト老混合した場合に注 2 水石こう単独の場合上の差は 認められないが， $\alpha$ ーアルミナを混合した場合は, 半水石

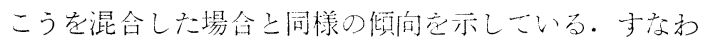
台， $\alpha$ ーアルミナの混合量の增加に之もなったAピークは 小さくなる。一方, Fig.7 上り半水不こうのBピーク注 汪上んよ゙変化しない。

以上の結果だけで法，こ礼らの変化の原因定明らが するこ之はできないが，DSC 法汇上る測定も DTA 法 の場合之同様に混合物の成分に上って測定するピークの 大きさに変化のあることは注意すべきことであるう．

3.3.2 半水石こう-無水石こう混合系 Fig. 8 法昇 温速度 $40^{\circ} \mathrm{C} / \mathrm{min}$ で測定した検量線で少る. Fig. 8 上 り半水石こうの含量こ B ピークの面積泣上い直線性を示 す. Table II 汇注, 昇温速度 $40^{\circ} \mathrm{C} / \mathrm{min}$ て測定したと きの再現性のみ示しているが，昗温速度の小さい $10^{\circ} \mathrm{C} /$

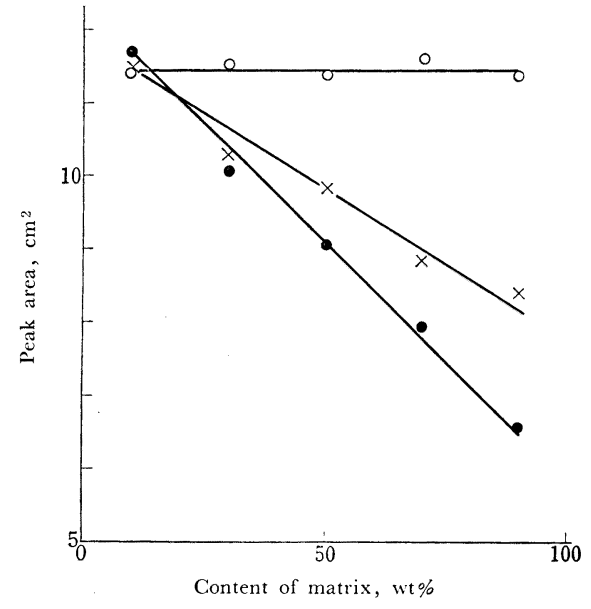

Fig. 6 The matrix effect on peak (A) area Heating rate : $40^{\circ} \mathrm{C} / \mathrm{min}$; Sample pan : Pin hole sample pan : Atmosphere : Self-atmosphere; Sample weight : $10 \mathrm{mg}$; $-\bigcirc-$ Graphite ; $-\times-\alpha$-Alumina ; - Calcium sulfate hemihydrate

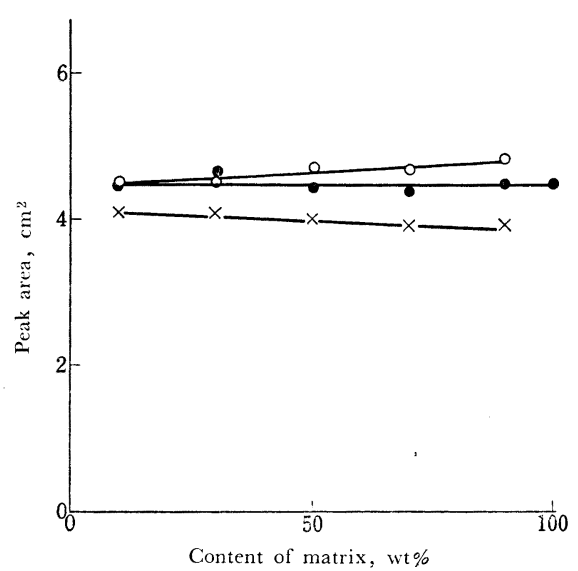

Fig. 7 The matrix effect on peak (B) area Heating rate : $40^{\circ} \mathrm{C} / \mathrm{min}$; Sample pan : Pin hole sample pan ; Atmosphere : Self-atmosphere; Sample weight : $10 \mathrm{mg}$; $-\mathrm{O}-$ Graphite; $-\mathrm{X}-\alpha$-Alumina ; - Calcium sulfate hemilsvdrate

min に予ける測定値の再現性のほうが良好である。しふ 乙分析時間短縮の点で $40^{\circ} \mathrm{C} / \mathrm{min}$ のほうが測定時間注 1/4 の $10 \mathrm{~min}$ で, 非常に短く, 標準偏差 3\% という 值は定量分析にとってわるい值ではない.したがってこ の系の測定も $40^{\circ} \mathrm{C} / \mathrm{min}$ の昇温速度で行なった。

再現性が 2 水石こう一半水石こう混合系と朔逆に, 昇 温速度が小さいほうが良好であることは，2 水石こうの 脱水により生成する半水石こうに水蒸気ふ九い気が大き な影響を及ぼすことを考虑す扎垱当然の結果である。 


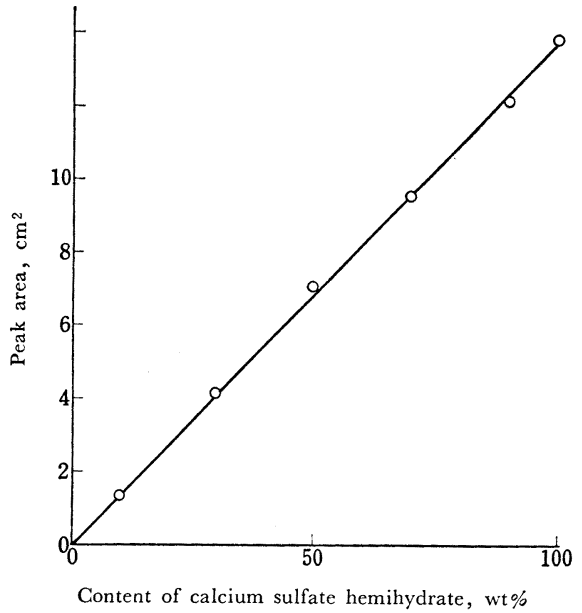

Fig. 8 Calibration curve of peak area vs. content of calcium sulfate hemihydrate by absolute method with DSC

Heating rate $: 40^{\circ} \mathrm{C} / \mathrm{min}$; Sample pan : Open sample pan; Atmosphere $: \mathrm{N}_{2}$; Sample weight $: 10 \mathrm{mg}$

\section{4 結論}

2 水石こう一半水石こう混合系および半水石こう一無水 石こう混合系の DSC 法による分析方法について検討し た結果, 熱分解時における水蒸気分圧を大きくするよう に試料を作製することによって，1 試料につき 10 分間 以内に標準偏差 $3 \%$ 程度で測定可能である. そして従来 より行なわれている DTA 法, TGA 法の所要時間約 1 時間と比較して，迅速性では数段すぐれた方法であると 結論できる。

終わりに，DSC の使用を許可された当試験場竹内貞 治化学部長ならびに横山督高分子研究室長に謝意を表 する。

\section{交献}

1) 高嶋四郎，橋詰源蔵，萩野友治：日塩誌， 10, 182 (1956).

2) 清水和雄，村上正祥，清水幸夫，竹中况三：同 上, 12, 130 (1958).

3）佐藤克哉，山崎 進，千住晃三：本誌，16，1040 (1967).

4) 関谷道雄, 瀬戸山克己：工化，69，1833 (1966).

5）千谷利三：“無機化学”, p. 238 (1959)，（産業 図書).

6）宮崎秀甫：工化，70，261（1967）.

红

Quantitative analysis of gypsum by differential scanning calorimetry, differential thermal analysis and thermogravimetric analysis. (Studies on technical analytical methods by differential scanning calorimetry, differential thermal analysis and thermogravimetric analysis. I.) Genzo Hashizume and Kayoko Amita (Industrial Research Institute, HyogoPref., Yukihira-cho, Suma-ku, Kobe-shi)

Methods for the analysis of $\mathrm{CaSO}_{4} \cdot 2 \mathrm{H}_{2} \mathrm{O}-\mathrm{CaSO}_{4}$. $1 / 2 \mathrm{H}_{2} \mathrm{O}$ and $\mathrm{CaSO}_{4} \cdot 1 / 2 \mathrm{H}_{2} \mathrm{O}-\mathrm{CaSO}_{4}$ with a differential scanning calorimeter (DSC) are presented, and the results are compared with those by differential thermal analysis(DTA) and thermogravimetric analysis(TGA).

It is already known that the endothermic peak of dehydration $\left(-3 / 2 \mathrm{H}_{2} \mathrm{O}\right)$ of $\mathrm{CaSO}_{4} \cdot 2 \mathrm{H}_{2} \mathrm{O}$ partially overlaps with that of dehydration $\left(-1 / 2 \mathrm{H}_{2} \mathrm{O}\right)$ of $\mathrm{CaSO}_{4} \cdot 1 / 2 \mathrm{H}_{2} \mathrm{O}$ in thermograms of DTA and DSC, but they are clearly separated on DSC curve by using sample pan with a cover having a pin hole and by carrying out the procedure in the self-generating atmosphere and at an increased heating rate, $40^{\circ} \mathrm{C} / \mathrm{min}$.

Determination of $\mathrm{CaSO}_{4} \cdot 1 / 2 \mathrm{H}_{2} \mathrm{O}$ in $\mathrm{CaSO}_{4} \cdot 1 / 2 \mathrm{H}_{2} \mathrm{O}$ $\mathrm{CaSO}_{4}$ is successfully done by using the open sample pan in nitrogen gas with the heating rate, $40^{\circ} \mathrm{C} / \mathrm{min}$.

Only $10 \mathrm{~min}$. is needed for one measurement and the relative standard deviation is less than $3 \%$.

The DSC method is much more simple and rapid than X-ray diffraction method, TGA and DTA.

(Received Dec. 2, 1968) 